\title{
Comparison of qualitative and quantitative alterations caused by use of various fixatives in the myocardium
}

\author{
Burcu İNSAL ${ }^{1, \mathrm{a}, \bowtie}$, İsmail Önder ORHAN ${ }^{1, \mathrm{~b}}$, Remzi Orkun AKGÜN ${ }^{1, \mathrm{c}}$, Mustafa KOÇKAYA ${ }^{2, \mathrm{~d}}$, \\ Nazlı TÜRKMEN ${ }^{3, \mathrm{e}}$, Barışhan DOĞAN,f

\begin{abstract}
${ }^{1}$ Ankara University, Faculty of Veterinary Medicine, Department of Anatomy, Ankara; ${ }^{2}$ Cumhuriyet University, Faculty of Veterinary Medicine, Department of Physiology, Sivas; ${ }^{3}$ Ankara University, Faculty of Agriculture, Department of Dairy Technology, Ankara; ${ }^{4}$ Ankara University, Faculty of Veterinary Medicine, Department of Microbiology, Ankara, Turkey.

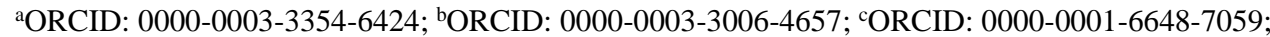
dORCID: 0000-0001-5173-0853; ' ORCID: 0000-0002-4219-8903; fORCID: 0000-0002-9151-9232
\end{abstract}

Corresponding author: binsal@ankara.edu.tr

Received date: 24.06.2019- Accepted date: 14.10.2019

\begin{abstract}
In the field of anatomy, preservation techniques used to preserve the integrity of specimens prepared for use as educational and research material are very ancient. It is desirable that these materials be as close as possible to the characteristics of living animal tissues in order to be an effective educational material. One of the most important criteria in determining similarity to fresh cadavers is the color and odor changes in the tissues. Therefore, the aim of this study is to reveal the anatomical and physiological changes on myocardial tissue, fixed by 4 different solutions in which qualitative and quantitative methods such as color analysis, sensory analysis, and microbiological tests. As a result, it was determined that a newly developed enriched saline solution and low concentration formaldehyde solution can be used safely for the preparation, preserve and long term use of educational materials.
\end{abstract}

Keywords: Colorimeter, fixation, sensory analysis, solution.

\section{Farklı tespit solüsyonları kullanımının miyokard üzerinde neden olduğu nitel ve nicel değişikliklerin karşılaştırılması}

Özet: Anatomi alanında, eğitim ve araştırma materyali olarak kullanılmak üzere hazırlanan örneklerin bozulmadan korunabilmesi için kullanılan prezervasyon teknikleri çok eski zamanlara dayanır. Bu materyallerin etkin bir eğitim materyali olabilmesi için mümkün olduğunca canlı hayvan dokularındaki özelliğe yakın olması istenir. Canlı hayvan dokularına benzerliğin belirlenmesindeki en önemli kıstaslarından biri şüphesiz ki dokulardaki renk değişimidir. Bu sebeple bu çalışmada, 4 farklı tespit solüsyonuyla hazırlanmış olan koyun kalplerindeki anatomik ve fizyolojik değişikliklerin, örneklere uygulanan renk analizi, duyusal analiz ve mikrobiyolojik testlerle nitel ve nicel olarak ortaya konulması amaçlandı. Sonuç olarak, yeni geliştirilen zenginleştirilmiş tuzlu su solüsyonu ile zenginleştirilmiş düşük konsantrasyonlu formaldehit solüsyonunun, eğitim materyallerinin hazırlanması, korunması ve uzun vadede kullanılabilir olması için güvenle kullanılabilecek solüsyonlar olduğu belirlendi.

Anahtar sözcükler: Duyusal analiz, kolorimetre, solüsyon, tespit.

\section{Introduction}

There are lots of anatomical techniques used for a long time to ensure that animal and human bodies are preserved intact after death as educational and research material. The process, first began with the mummification of corpses in Egypt and Chinchorro (a region of Arica, Chile and Peru coast) cultures in the years 7000-5000 BC and has continued to until development of various methods like as the plastination technique, which was developed by Gunter von Hagens in the late 1970s (2, 6, 12, 24). As written in many articles, cadaver-based education is used not only for the anatomy but also for clinical sciences teaching, especially surgery. It is desirable that these cadavers, which are used for practice, should have a similar quality to fresh cadavers, in order to be an effective educational material, if it is possible $(8,9$, $17,21,25,29)$. However, in recent years, studies on the development of different cadaveric preparation techniques have begun to increase especially with the increase of ethical rules, in order to reduce the use of cadavers prepared from alive animals (26). Although new fixatives have been developed with varied techniques and laboratory process, decomposition is still not completely prevented. Because of the physiological parameters 
change when the cells and tissues are taken out from the body. Accordingly, a number of pathological reactions such as putrification and autolysis are formed. In other words, the changes are caused by putrification, which is formed by the bacterial activation and autolysis, which is developed with the release of intracellular autolytic substances, after physiological death occur. When considered at the cellular mechanism, firstly cytoplasmic content and lysosomal enzymes are released outside the cell; necrotic cell death and diffuse tissue damage are observed $(19,20)$. Because of these reactions, one of the most important criteria of decomposition is the color change that occurs in tissues. The color changes of tissues can be displayed on the $\mathrm{X} / \mathrm{Y}$ coordinates and can be computed numerically in the CIE (International Lighting Commission) $\mathrm{L}^{*} \mathrm{a}^{*} \mathrm{~b}$ ( system standards via the usage of the tristimulus color measurement devices $(3,13,14,18$, 28).

The aim of this study was to quantitatively evaluate the anatomical and physiological changes in sheep hearts, which were fixed in 4 different fixation solutions, by color measurement and microbiological analysis. In addition, the study was qualitatively strengthened with the sensory analysis test applied to semi-educated panelists. Two of the four fixatives used here were newly developed and their effectiveness were demonstrated.

\section{Material and Methods}

When determining the sample to be used in the study the Power of test $(1-\beta)$ was 0.80 calculated by G. Power statistical Packet software. Accordingly, a total of 35 sheep hearts obtained from a licensed slaughterhouse in Ankara Province were used. Cardiac tissue was preferred in the study both it is an organ with high blood content anatomically and it has striated muscles that perform at high capacity physiologically. The samples were initially divided into 5 different groups that one of them would being a control. For this purpose, 4 different fixation solutions were prepared. The whole groups were named according to the content of solutions. The first group is a saline solution (SS) that prepared with low concentration saline $(<20 \%)$. The second group is an enriched saline solution (INSALT) that prepared with $26.5 \%$ saline, ethyl alcohol, polyethylene glycol, and citric acid. The third solution is a $10 \%$ formaldehyde solution (FS), a strong disinfectant. The fourth solution is the lower concentration of formaldehyde enriched with ethyl alcohol and polyethylene glycol (EFS). Moreover, in the fifth group, the samples kept in $+4 \mathrm{C}^{\circ}$ in the refrigerator without any solutions for being control. The salt used in the first and second groups for fixation; was used since it serves to adjust the osmotic structure of the solutions and the acid-base balance. It is also preferred inasmuch as it is the cheapest, non-toxic and most easily accessible chemistry available in fixatives $(4,10)$. Despite all the known toxic effects and disadvantages, formaldehyde, which is still widely used, was utilized in the third and fourth solutions $(5,6,11)$. The ethyl alcohol used in the second and fourth groups was preferred because of its bactericidal, antiviral, antifungal and antimycotic effects as well as its ability to easily penetrate into deep tissues and increase the effectiveness of formaldehyde. Polyethylene glycol was added to the solutions as it increased the disinfectant effect of formaldehyde and reduced mold formation when used together with formaldehyde $(2,6,15)$. In addition, the citric acid used in the third solution was added to the mixture due to the known antioxidant and anticoagulant properties $(22,23)$. Besides, in the fourth group formaldehyde was used at a very low concentration of $0.5 \%$ to reduce the toxicity ratio of the solution. A total of 35 sheep hearts, 7 specimens for each group, were obtained from a licensed slaughter house. The organs were brought to the laboratory within post-mortem first hour. Each was then numbered separately. In the study, a colorimeter device (Konica Minolta CR-400) with the capability to obtain results on international $\mathrm{L}^{*} \mathrm{a}^{*} \mathrm{~b}^{*}$ measurement standards was utilized to determine the color alteration (14). The measurements were taken from 3 dividual points on the myocardial tissue to increase the accuracy of the results and estimate the averages statistically. While these mentioned three points were determined, the hearts were arranged on the bench floor where the facies auricularis would get in touch with. The first landmark; right side of sulcus interventricularis paraconalis, the second marker point; left side of sulcus interventricularis paraconalis and the third marker point is apex cordis of the organ was preferred. Then, all samples were made post-mortem initial measurements from marked-point without any process. Then, the postmortem initial measurements on the marked-point of organs were received from all samples without any process. All samples were taken in organ storage containers containing divergent fixatives. The samples which were not treated with any solution were put in an airtight and closed container and kept in the refrigerator at $+4{ }^{\circ} \mathrm{C}$ for storage. The measurements were received on post-mortem first day and repeated on the $7^{\text {th }}, 15^{\text {th }}, 30^{\text {th }}$, $60^{\text {th }}$ days and $1^{\text {st }}$ year in order to observe the timedependent effect of anatomical and physiological changes. Besides, total bacteria, total fungus and yeast were examined from the specimens collected from surface and deep of cadaver and the fixation solutions at the end of the study for all groups. In addition, the sensorial properties of the samples were determined by 7 semi-trained panelists using scoring test modified from Meilgaard et al. (16) at the end of the experiment. A fresh cadaver sample was given to the panelists as the control sample and they were asked to evaluate the similarities of the samples were 
kept in SS, INSALT, FS and EFS in terms of appearance, odor and texture (elasticity) over 9 points compared to the control sample. The panelists rated the samples named A, $\mathrm{B}, \mathrm{C}, \mathrm{D}$ without informing them about the solutions. In the new marking for panelists, letters described the solutions. Accordingly, to 'A' was the saline solution, 'B' was enriched saline solution; ' $\mathrm{C}$ ' was the formalin solution, and 'D' was enriched formaldehyde solution.

The color changes $\left(L^{*} a^{*} b^{*}\right)$ of the five different groups on the different days and sensory analyses data were compared with the repeated measure ANOVA test $\left(1^{\text {st }}, 7^{\text {th }}, 15^{\text {th }}, 30^{\text {th }}, 60^{\text {th }}\right.$ days and $1^{\text {st }}$ year $)$. Duncan multiple comparison tests were used for determining which groups were different if groups were identified as important. Statistical analyses were estimated by SPSS v.15 packet program.

\section{Results}

The samples in the low concentration saline solution were removed, notwithstanding color change, from the experiment on the $8^{\text {th }}$ day. Because of the perforation and deterioration of the organs, there was a severity bad smell affecting the vomiting center. Similarly, the fifth group which formed the control group of the study, was removed on the $15^{\text {th }}$ day for the same reasons. According to the obtained data; the closest values of the brightness from the white $\left(\mathrm{L}^{*}\right)$ and the color change from red to green $\left(\mathrm{a}^{*}\right)$ and from yellow to blue $\left(b^{*}\right)$ to the fresh tissue was observed from the enriched formaldehyde solution (EFS) at the end of the $1^{\text {st }}$ year (Table 1). While the $10 \%$ formaldehyde solution increased the luminosity $\left(\mathrm{L}^{*}\right)$ value of the organs by approximately 26.15 units, it reduced the red color by 12.37 units. Therefore, it was observed that the color of organs was changed to the different shades of gray. In addition, it was observed that these organs lost elasticity of the tissues in parallel with they were durable and extremely rigid. The samples waiting in the INSALT solution lost the reddish color approximately 12.69 units and the yellow color by 0.18 units while increased the brightness only by 5.55 units, during the first year (Table 1). However, it was observed that these samples were more vivid than the waiting samples in the $10 \%$ formaldehyde solution. When all of the data were obtained, the results were significant on the brink of $\mathrm{P}<0.05$ statically (Table 1 ). In addition; no perforation or malodor formation was observed in specimens waiting in this solution. On the contrary, it was noted that the specimens were so durable, robust and at the same time, they were quite elastic that they could be used in training. According to the results of the sensory analysis performed, sample D was prepared with EFS was the most similar sample to the fresh cadaver (control sample) in terms of appearance, odor and textural (elasticity) characteristics. Sample D was described by the panelists as "almost the same as the control sample", followed by sample B was prepared with INSALT, C was prepared with FS and A

Table 1. Color change graphic on the myocardium according to days.

\begin{tabular}{llcccccc}
\hline & & $\begin{array}{c}\text { Control } \\
\left(\sum \pm \text { SEM) }\right.\end{array}$ & $\begin{array}{c}\text { SS } \\
\left(\sum \pm \text { SEM }\right)\end{array}$ & $\begin{array}{c}\text { INSALT } \\
\left(\sum \pm \text { SEM }\right)\end{array}$ & $\begin{array}{c}\text { FS } \\
\left(\sum \pm \text { SEM }\right)\end{array}$ & $\begin{array}{c}\text { EFS } \\
\left(\sum \pm \text { SEM }\right)\end{array}$ & P \\
\hline \multirow{2}{*}{$1^{\text {st }} \mathrm{d}$} & $\mathrm{L}^{*}$ & $38.66 \pm 1.15^{\mathrm{b}}$ & $40.99 \pm 0.89^{\mathrm{b}}$ & $39.81 \pm 0.80^{\mathrm{b}}$ & $35.12 \pm 0.72^{\mathrm{a}}$ & $39.81 \pm 1.08^{\mathrm{b}}$ & $* * *$ \\
& $\mathrm{a}^{*}$ & $18.94 \pm 0.62$ & $17.79 \pm 0.39$ & $17.41 \pm 0.46$ & $19.02 \pm 0.54$ & $18.28 \pm 0.69$ & - \\
& $\mathrm{b}^{*}$ & $12.08 \pm 0.71^{\mathrm{b}}$ & $12.64 \pm 0.54^{\mathrm{b}}$ & $11.88 \pm 0.37^{\mathrm{b}}$ & $9.94 \pm 0.68^{\mathrm{a}}$ & $12.12 \pm 0.56^{\mathrm{b}}$ & $*$ \\
& $\mathrm{~L}^{*}$ & $34.38 \pm 0.74^{\mathrm{a}}$ & $49.65 \pm 2.82^{\mathrm{c}}$ & $39.10 \pm 1.04^{\mathrm{b}}$ & $47.36 \pm 0.66^{\mathrm{c}}$ & $39.76 \pm 1.36^{\mathrm{b}}$ & $* * *$ \\
\hline $7^{\mathrm{th}} \mathrm{d}$ & $\mathrm{a}^{*}$ & $16.25 \pm 0.76^{\mathrm{c}}$ & $7.46 \pm 0.51^{\mathrm{b}}$ & $5.38 \pm 0.20^{\mathrm{a}}$ & $8.63 \pm 0.21^{\mathrm{b}}$ & $17.15 \pm 0.59^{\mathrm{c}}$ & $* * *$ \\
& $\mathrm{~b}^{*}$ & $5.00 \pm 0.20^{\mathrm{a}}$ & $10.65 \pm 0.41^{\mathrm{b}}$ & $13.54 \pm 0.67^{\mathrm{c}}$ & $10.07 \pm 0.67^{\mathrm{b}}$ & $12.56 \pm 0.94^{\mathrm{c}}$ & $* * *$ \\
& $\mathrm{~L}^{*}$ & $36.92 \pm 0.65^{\mathrm{a}}$ & - & $38.98 \pm 1.16^{\mathrm{a}}$ & $47.35 \pm 0.48^{\mathrm{b}}$ & $39.85 \pm 1.36^{\mathrm{a}}$ & $* * *$ \\
\hline $15^{\text {th }} \mathrm{d}$ & $\mathrm{a}^{*}$ & $12.32 \pm 0.42^{\mathrm{c}}$ & - & $5.36 \pm 0.26^{\mathrm{a}}$ & $8.61 \pm 0.20^{\mathrm{b}}$ & $17.26 \pm 0.63^{\mathrm{d}}$ & $* * *$ \\
& $\mathrm{~b}^{*}$ & $7.55 \pm 0.42^{\mathrm{a}}$ & - & $13.77 \pm 0.49^{\mathrm{c}}$ & $9.79 \pm 0.60^{\mathrm{b}}$ & $12.61 \pm 0.86^{\mathrm{c}}$ & $* * *$ \\
& $\mathrm{~L}^{*}$ & - & - & $39.45 \pm 1.14^{\mathrm{a}}$ & $47.27 \pm 0.63^{\mathrm{b}}$ & $39.03 \pm 1.36^{\mathrm{a}}$ & $* * *$ \\
\hline $30^{\text {th }} \mathrm{d}$ & $\mathrm{a}^{*}$ & - & - & $5.21 \pm 0.21^{\mathrm{a}}$ & $8.67 \pm 0.16^{\mathrm{b}}$ & $17.33 \pm 0.69^{\mathrm{c}}$ & $* * *$ \\
& $\mathrm{~b}^{*}$ & - & - & $13.12 \pm 0.70^{\mathrm{b}}$ & $10.11 \pm 0.57^{\mathrm{a}}$ & $13.72 \pm 0.80^{\mathrm{b}}$ & $* *$ \\
& $\mathrm{~L}^{*}$ & - & - & $41.11 \pm 1.42^{\mathrm{a}}$ & $48.00 \pm 0.71^{\mathrm{b}}$ & $39.20 \pm 1.50^{\mathrm{a}}$ & $* * *$ \\
\hline $60^{\text {th }} \mathrm{d}$ & $\mathrm{a}^{*}$ & - & - & $4.77 \pm 0.27^{\mathrm{a}}$ & $8.29 \pm 0.24^{\mathrm{b}}$ & $16.57 \pm 0.62^{\mathrm{c}}$ & $* * *$ \\
& $\mathrm{~b}^{*}$ & - & - & $12.16 \pm 0.67^{\mathrm{b}}$ & $10.11 \pm 0.65^{\mathrm{a}}$ & $13.76 \pm 0.71^{\mathrm{b}}$ & $* *$ \\
& $\mathrm{~L}^{*}$ & - & - & $45.36 \pm 1.27^{\mathrm{a}}$ & $61.27 \pm 1.70^{\mathrm{b}}$ & $41.36 \pm 1.42^{\mathrm{a}}$ & $* * *$ \\
\hline $1^{\mathrm{st}} \mathrm{y}$ & $\mathrm{a}^{*}$ & - & - & $4.72 \pm 0,35^{\mathrm{a}}$ & $6.65 \pm 0.28^{\mathrm{b}}$ & $16.43 \pm 0.53^{\mathrm{c}}$ & $* * *$ \\
& $\mathrm{~b}^{*}$ & - & - & $11.70 \pm 0.58^{\mathrm{b}}$ & $9.08 \pm 0.57^{\mathrm{a}}$ & $12.21 \pm 0.64^{\mathrm{b}}$ & $* *$ \\
\hline
\end{tabular}

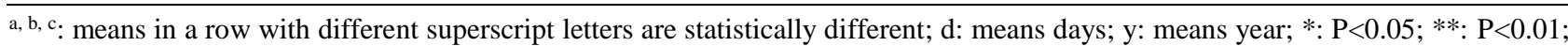
***: P<0.001, -: P>0.05 (insignificant). SS: Saline solution; INSALT: Enriched saline solution; FS: Formalin solution; EFS: Enriched formaldehyde solution. 
Table 2. Sensory analyses of the heart samples for all groups.

\begin{tabular}{lcccc}
\hline & A & B & C & D \\
& $\left(\sum \pm\right.$ SEM) & $\left(\sum \pm\right.$ SEM) & $\left(\sum \pm\right.$ SEM) & $\left(\sum \pm\right.$ SEM) \\
\hline Apperance & $0.29 \pm 0.49$ & $7.57 \pm 1.13$ & $6.43 \pm 0.79$ & $8.67 \pm 0.52$ \\
Odor & $0 \pm 0$ & $7.29 \pm 0.95$ & $5.29 \pm 0.95$ & $8.00 \pm 071$ \\
Texture (Elasticity) & $0.29 \pm 0.49$ & $8.00 \pm 0.89$ & $3.86 \pm 0.90$ & $7.14 \pm 0.90$ \\
\hline
\end{tabular}

*The degree of similarity of the samples to the control sample was evaluated between 0 and 9 points. A: Saline solution (SS); B: Enriched saline solution (INSALT) C: Formalin solution (FS); D: Enriched formaldehyde solution (EFS).

was prepared with SS, respectively. In addition, all panelists stated that $\mathrm{A}, \mathrm{B}$, and $\mathrm{D}$ did not have a chemical smell, while 5 panelists indicated that sample $\mathrm{C}$ had a disturbing chemical smell. The sample A received lowest scores (Table 2) for all properties analysed and all of the panelists indicated that there was no similarity between sample A and the control sample. It has also been noted there was purification in sample A by all the panelists. Besides no pathogenic microorganisms have been detected in the samples keeping in INSALT, FS and EFS solutions analysed for total bacteria, total fungus, and yeasts. However, high levels of bacteria, fungi, and yeast were found in the samples that were control and waiting in SS solution. At the end of the $15^{\text {th }}$ day, in the total bacteriological culture analysis of the samples kept in the SS fixative; Lactobacillus spp. and E. coli, in the total fungal analysis; Penicillium spp., Aspergillus spp., Fusarium spp. and Rhizopus spp., in the total yeast analysis; Candida spp. and Saccharomyces spp. were isolated and identified. On the contrary, even at the end of the study, no pathogenic microorganisms mentioned above were found in the other groups.

\section{Discussion and Conclusion}

Many studies have confirmed that chemical fixation solutions used when preparing cadaver by classical methods have risks in terms of human health $(1,2,4-6,10$, 12). For this reason, the effects of 4 different fixative solutions that include formaldehyde and nonformaldehyde on heart tissue were studied in this study. When choosing the fixative solutions, the $10 \%$ formaldehyde solution, which is known to be toxic and which is still used despite all its disadvantages, and saline solution, which is totally nontoxic and controversial to use alone despite its many advantages, were preferred. In contrast to Bakici et al. (3), fixatives used in the past with high formaldehyde concentrations were not modified in this study. Low concentration formaldehyde and high degree saline solutions were prospered with other chemicals as ethyl alcohol, polyethylene glycol, citric acid directly in this study. Thereby new fixative solutions were developed by this study. These new solutions and other known solutions were compared in terms of the positive and negative aspects of the effects on the hearts. The newly developed fixation solutions were examined in terms of their preparation methods, ease of handling and their impact on myocardial tissue. In the light of this information, the choice of the fixatives was left to the preference of the researchers in all aspects. The theory that saline solution is an unsuccessful fixation solution when used at a concentration lower than $20 \%$ as explained by Fricker et al. (7) is confirmed by this study. Similar to the article by Janczyk et al. (10), the salt was utilized in this experiment for targeting develop a non-toxic fixative. However, contrary to Janczyk et al. (10) the salt was used not rate of $23 \%$, was added the mixture at a rate of $26.5 \%$, which would produce a saturated salt water concentration. In contrast to Janczyk et al. (10) instead of 3\% ascorbic acid, the 5\% citric acid, which due to known anticoagulant and antioxidant properties was supplemented in INSALT solution. Some literature $(6,11,27)$ examining the color changes in the tissues have observed that the cadaver was got lost their color, based on fixatives consisting of formaldehyde coagulates the blood rapidly. This situation was confirmed with samples fixed in $10 \%$ formaldehyde solution quantitatively by approximately 26.15 units increased brightness degree and 12.37 units changed reddish color to green. On the other hand, as a result of decreasing the formaldehyde ratio to $0.5 \%$ in the EFS, it was observed that the samples detected with this solution best preserved the color and were the closest samples to fresh tissue. Thus, it was revealed that EFS can be utilized because being both a less toxic and efficient fixative by this study.

As a result, the deterioration effects of the fixatives in which the tissues and organs prepared to be used as educational material in the field of anatomy were examined in terms of color variance on the sheep heart. These color changes were quantified for the first time, and all obtained data were compared to compose meaningful results between groups statistically (Figure1). As a result of the research, it was concluded that samples which were fixed with the low concentration of saline solutions and kept without any treatment were not possible to use for a long time in education. The microbiological results revealed that Turan et al. (27) encountered Bacillus spp. 


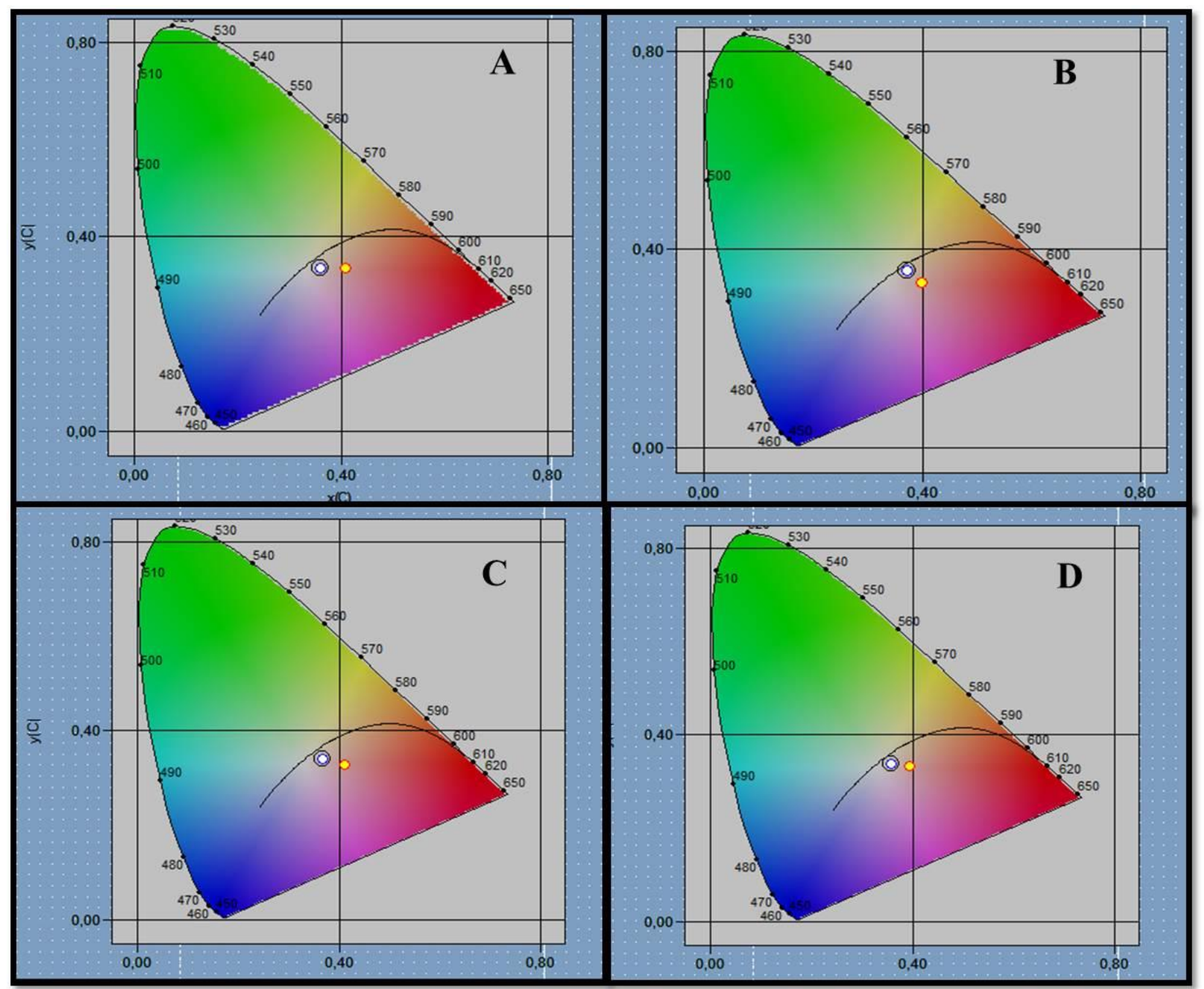

Figure 1. Color change chart; A: Saline solution (SS); B: Enriched saline solution (INSALT); C: Formalin solution (FS); D: Enriched formaldehyde solution (EFS).

rarely. In this study, Bacillus spp. and other microorganisms that mentioned in the results were observed in control and SS group. However, no microorganisms including Bacillus spp. were found in other groups (FS, EFS, INSALT). Accordingly, EFS and INSALT solution delayed decomposition as FS and could be used during the preparation of training materials. Also, the results of the sensory analyses were found to support these data.

Consequently, it was detected that the INSALT solution can be preferred for the preparation of organs to be used as training material. Because there are many advantages such as being a non-toxic solution, durability, and elasticity of the organs and color change rates in tissues similar to fresh tissue. Despite the fact that the EFS solution contains formaldehyde in low concentrations, it can be safely used for the preparation of organs in anatomy training. Because it has positive effects on the organs likewise the INSALT solution. Based on the data obtained from this study, it is planned to work on the fixation of whole-body cadavers and organs of other mammals and avian with these solutions.

\section{Acknowledgements}

The newly developed solution named "Salt Content Cadaver Solution (INSALT)" was registered by the Turkish Patent and Trademark Office owned by Ankara University with reference number $2018 / 08311$ on the date of 11.06.2018.

\section{Conflict of Interest}

The authors declared that there is no conflict of interests.

\section{References}

1. Ajayi IE, Shawulu JC, Ghaji A, et al (2011): Use of formalin and modified gravity-feed embalming technique in veterinary anatomy dissection and practicals. J Vet Med Anim Health, 3, 79-81. 
2. Al Aiyan A, Weigner J, Lübke-Becker A, et al (2012): Long term study on microbial status in anatomical cadaver fixation using reduced formalin concentration. BJVM, 15, 74.

3. Bakici C, Akgün RO, Ekim O, et al (2017): Is kaiserling solution a convenient fixative for mammalian organ specimens? Evaluation of morphometric, colorimetric and volumetric properties. BJVM, 20, 62-67.

4. Batra APS, Khurana BS, Mahajan A, et al (2010): Embalming and other methods of dead body preservation. IJMTFM, 12, 12-19.

5. Bendino JH (2003): Embalming chemistry: glutaraldehyde versus formaldehyde. Avaliable at https://pdfs.semanticscholar.org/3fb1/19f2bd6276f76522b 192a63077a5f6019f68.pdf (Accessed October 10, 2017).

6. Brenner E (2014): Human body preservation - old and new techniques. J Anat, 224, 316-344.

7. Fricker J, Zeiler E, McDaniel BJ (2007): From formalin to salt. Development and introduction on a salt-based preserving solution for macroscopic anatomic specimens. Tierarztl Prax Ausg K Kleintiere Heimtiere, 35, 243-248.

8. Hammer N, Löffler S, Bechmann I, et al (2015): Comparison of modified thiel embalming and ethanolglycerin fixation in an anatomy environment: potentials and limitations of two complementary techniques. Ana Sci Educ, 8, 74-85.

9. Inglez DS, Matera JM (2015): Bleeding simulation in embalmed cadavers: bridging the gap between simulation and live surgery. ALTEX, 32, 59-63.

10. Janczyk P, Weigner J, Luebke-Becker A, et al (2011a): Nitrite pickling salt as an alternative to formaldehyde for embalming in veterinary anatomy - A study based on histoand microbiological analyses. Ann Anat, 193, 71-75.

11. Janczyk P, Weigner J, Luebke-Becker A, et al (2011b): A pilot study on ethanol-polyethylene glycol-formalin fixation of farm animal cadavers. Berl Münch Tierärztl Wochenschr, 124, 225-227.

12. Jangde S, Arya RS, Paikra S, et al (2015): How to provide a safe working condition for medical students and professionals in the anatomy dissection room. Sch J App Med Sci, 3, 1867-1870.

13. Kays SJ (1999): Preharvest factors affecting appearance. Postharvest Biol Technol, 15, 233-247.

14. Leon K, Mery D, Pedreschi F, et al (2006): Color measurement in $L^{*} a * b *$ units from $R G B$ digital images. Food Res Int, 39, 1084-1091.

15. MacDonald GJ, MacGregor DB (1997): Procedures for embalming cadavers for the dissecting laboratory. Proc Soc Exp Biol Med, 215, 363-365.
16. Meilgaard M, Civille GV, Carr T (1999): Sensory evaluation technique. CRC Press, USA.

17. O'neill GJ, Pais D, de Andrade FF, et al (2013): Improvement of the embalming perfusion method: The innovation and the results by light and scanning electron microscopy. Acta Med Port, 26, 188-194.

18. Oliveria AC, Balaban MO (2006): Comparison of a colorimeter with a machine vision system in measuring color of Gulf of Mexico sturgeon fillets. Appl Eng Agric, 22, 583-587.

19. Persnell SE (2015): Postmortem changes. Available at https://emedicine.medscape.com/article/1680032-overview (Accessed May 10, 2017).

20. Plymale DR, Tang DS, Comardelle AM, et al (1999): Both necrosis and apoptosis contribute to HIV-1 induced killing of CD4 cells. AIDS 13, 1827-1839.

21. Rai BP, Tang B, Eisma R (2012): A qualitative assessment of human cadavers embalmed by Thiel's method used in laparoscopic training for renal resection. Anat Sci Educ, 5, 182-186.

22. Ryan EM, Duryee MJ, Hollins A (2019): Antioxidant properties of citric acid interfere with the uricase-based measurement of circulating uric acid. J Pharm Biomed Anal, 164, 460-466.

23. Rostamzad H, Shabanpour B, Kashaninejad M, et al (2011): Antioxidative activity of citric and ascorbic acids and their preventive effect on lipid oxidation in frozen persian sturgeon fillets. Lat Am Appl Res, 41, 135-140.

24. Saeed M, Rufai AA, ElSayed SE et al (2001): Mummification to plastination. Saudi Med J, 22, 956-959.

25. Silva RMG, Matera JM, Ribeiro AACM (2004): Preservation of cadavers for surgical technique training. Vet Surg, 33, 606-608.

26. Silva RMG, Matera JM, Ribeiro AACM (2007): New alternative methods to teach surgical techniques for veterinary medicine students despite the absence of living animals. Is that an academic paradox? Anat Histol Embryol, 36, 220-224.

27. Turan E, Gules O, Kilimci FS, et al (2017): The mixture of liquid foam soap, ethanol and citric acid as a new fixative-preservative solution in veterinary anatomy. Ann Anat, 209, 11-17.

28. Vanezis P, Trujillo O (1996): Evaluation of hypostasis using a calorimeter measuring system and its application to assessment of the post-mortem interval (time of death). Forensic Sci Int, 78, 19-21.

29. Winkelmann A (2007): Anatomical dissection as a teaching method in medical school: A review of the evidence. Med Educ, 41, 15-22. 